\title{
Human resource policy makers', teachers', and adult learners' views on the impact of context- and teacher-generated autonomy on adult learners' L2 motivation: Interview studies in Hungarian corporate contexts
}

\author{
CSABA KÁLMÁN* \\ Department of English Applied Linguistics, Eötvös Loránd University, Budapest, Hungary
}

(Received: November 3, 2018; accepted: March 23, 2019)

\begin{abstract}
Although the indisputable importance of autonomy, partly due to its motivating capacity, is firmly anchored both in the theory of second-language acquisition and adult education at large, the cross section of the two fields, that is the autonomy of adult language learners, has received little attention in the literature. If we focus on the autonomy of adult language learners in corporate contexts, empirical studies are practically non-existent. This paper fills this niche by synthesizing the findings of 4 interview studies conducted in 18 organizations in Hungary. In this study, 19 human resource policy makers, 18 second-language (L2) teachers, and 21 adult learners were interviewed using a semistructured interview guide to explore how corporate contexts and their language teachers fostered autonomous language learning and how it affected adult learners' L2 motivation. Results show that while these contexts promote autonomy through their ongoing organic development, teachers foster it by being responsive to learners' needs, and by providing choices to learners on the basis of which tailor-made teaching is made feasible.
\end{abstract}

Keywords: adult learning; L2 motivation; L2 autonomy; corporate contexts

\section{INTRODUCTION}

Although the indisputable importance of autonomy is firmly anchored both in the theory of second-language acquisition (e.g., Benson, 2011; Chik, Aoki, \& Smith, 2018; Smith, Kuchah, \& Lamb, 2018) and adult education at large (e.g., Fejes, Olson, Rahm, Dahlstedt, \& Sandberg, 2018; Knowles, 1975a; Rogers \& Mitzner, 2017), the cross section of the two fields, that is, the autonomy of adult language learners, has received little attention in the literature. This is surprising for two reasons. First, lifelong learning in developed economies is currently being given an unprecedented amount of consideration (Billett, 2018); second, secondlanguage (L2) autonomy research seems to have neglected its origins, which arise from adult learning in the 1970s (Riley, 1985).

If we consider the first reason, it must be noted, however, that lifelong learning is increasingly viewed with the aim of attaining such tangible results that can be utilized in employment (Billett, 2018). There is no doubt that foreign language skills in corporate contexts fall in this category. As for the second reason, even though the focus of L2 autonomy research has currently been the context of primary, secondary, and tertiary education, the foundations of autonomy in language learning arise from adult language learning (Benson, 2011), and the original motive behind the initiative of The Council of Europe (1997) to introduce Europe's Modern Languages Project was "to provide adults with opportunities for lifelong learning and the approach developed [...] was influenced by proposals from the emerging field of adult self-directed learning" (Benson, 2011, p. 10).

The current abundance of lifelong learning programs calls for broadening L2 autonomy research by extending the research agenda to devote more attention to the initial target audience of L2 autonomy, adult learners as well. It was this call that inspired me to investigate the role of context- and teacher-generated learner autonomy on the adult L2 learners' motivation. For the context of this investigation, the most straightforward, yet underresearched, environment has been selected where lifelong learning promises applicable results in employment corporate contexts. This choice was also guided by the fact that a majority of organizations today are knowledge organizations (Kálmán, 2015a, 2016a) that are aware of the necessity of lifelong learning, which they promote by continuously training their employees. In addition, I was also driven by the recent resurgence of scholarly interest in the teacher's role in L2 motivation research (Csizér, 2018, 2019; Dewaele, Gkonou, \& Mercer, 2018; Kálmán, 2018; Lamb, 2017; Mercer et al., 2017; Smid, 2018) with a view to finding out what role the teacher plays in enhancing motivation by fostering L2 autonomy in the context investigated.

\footnotetext{
* Correspondence: Csaba Kálmán, Department of English Applied Linguistics, Eötvös Loránd University, Rákóczi út 5., 1088 Budapest, Hungary; Phone: +36 3047 72555; Fax: +36 1460 4413; e-mail: csabakalman73@gmail.com
}

This is an open-access article distributed under the terms of the Creative Commons Attribution 4.0 International License, which permitsunrestricted use, distribution, and reproduction in any medium, provided the original author and source are credited, a link to the CC License is provided, and changes - if any - are indicated. (SID_1) 
This paper synthesizes the findings of previous studies (Kálmán, 2015a, 2015b, 2016b, 2018) conducted in corporate environments and focuses on the role of context- and teacher-generated autonomy on L2 motivation. By presenting the views of 19 human resource (HR) managers, 18 L2 teachers, and 21 adult learners on how autonomy fostered by the learning environment and language teachers affects L2 motivation in corporate contexts, this paper sheds light on the intricate interrelatedness of language-learning autonomy and motivation in corporate contexts.

\section{LITERATURE REVIEW}

\section{Context}

As a result of the political, economic, and social changes that have taken place in Hungary, the importance of the English language has gained increasing ground on the Hungarian labor market ever since the political changes in the country at the beginning of the 1990s (Földi, László, Szücs, \& Máté, 2013). English has become the lingua franca of the modern age, the negotiating language of professional and business life (Sturcz, 2010). Its most important role, however, is that it has become the means of acquiring knowledge capital, as the vast majority of professional literature is born in this language (Sturcz, 2010). In spite of the facts that an intermediate command of English is already regarded as a basic skill on the labor market, and an overwhelming majority of company entrants in the investigated context possess it, over $91 \%$ of big corporations (employing over 250 employees) support the language education of their workforce up to this day in Hungary (Központi Statisztikai Hivatal [Hungarian Statistical Office], 2016). This is not surprising if we consider that organizations view knowledge as a strategic tool (Hislop, Boshua, \& Helms, 2018), and its real benefit is manifested in an increase in the financial results and competitiveness of the organization (Lakner, 2016).

According to Sturcz (2010), speaking English today is essential in the corporate world, and the expectancy ratio has increased to $98 \%$ from $88 \%$ a decade ago. Nevertheless, it does not necessarily mean that the English knowledge of graduates meets corporate norms, even if they have passed a B2-level language exam. Potential candidates need to have a working knowledge of English, which - in the case of English - primarily means communication with non-native speakers of English. Kontráné and Csizér (2011) base this argument on the fact that on a global scale, today, there are four times as many non-native speakers of English as natives, and the lion's share of English communication takes place between non-native speakers of English (Graddol, 2006).

\section{Autonomy in the workplace}

Adult learning in corporate contexts provides employees with the prospect of professional development, which is one of the three cornerstones of modern motivation theories in the workplace (Pink, 2009). The central tenets of Pink's (2009) motivation theory draw on Deci and Ryan's (1985) Self-Determination Theory (SDT) and Csikszentmihalyi's (1988) concept of flow. Deci and Ryan (1985) argue that we have three innate psychological needs: competence, autonomy, and relatedness. When these needs are satisfied, we become motivated, productive, and happy. Conversely, when they are inhibited, our motivation, productivity, and sense of satisfaction plummet. As a consequence of this, it would be desirable for us to create such environments in our workplaces where our innate psychological needs can flourish. At the positive extreme of the fulfillment of this condition, we can find a very productive, heightened state of mind, which is referred to as flow by Csikszentmihalyi (1988). When these environmental prerequisites are met, autonomy, mastery, and purpose lead to a high level of motivation (Pink, 2009).

Pink (2009) does not equate autonomy - the first of the three components - with independence. In his view, autonomy provides working adults with a choice, which can include being both autonomous and readily interdependent with others. It comprises autonomy over what one does, when one does it, who one does it with, and how one does it. The pursuit of mastery, the second ingredient of Pink's (2009) theory requires an inquisitive, discerning mind, and the willingness to experiment one's way to a fresh solution (Dutton \& Wrezniewsky, 2001). Mastery can be characterized by three peculiar rules: first of all, it is a mindset, as it requires the capacity to see one's abilities as infinitely improvable, as well as the willingness to improve one's abilities. Second, mastery requires effort and deliberate practice. Third, mastery is an asymptote (a mathematical function, a straight line approached by a given curve more and more but never reached by it) as it is impossible to fully realize, which makes it simultaneously frustrating, challenging, and attractive.

The third component of the theory, purpose, provides a context for the first two. When people are highly motivated, they connect their desires to a cause that is greater and more enduring than themselves, and is not only concerned with their well-being. An implicit way of the manifestation of purpose is facilitated by corporate policies that allow employees to pursue purpose autonomously, on their own terms. These corporate policies enable employees to do so by allowing them to feel that they belong to something greater and more permanent than themselves and give them room and time to fulfill their purposes (Shanafelt, Balch, \& Bechamps, 2009).

\section{LIFELONG LEARNING}

Pink's (2009) three core components of motivation in the workplace (autonomy, mastery, and purpose) resemble three of Knowles' (1980, 1984) five assumptions about the characteristics of adult education (andragogy), which provides a framework for adults' lifelong learning. In 1980, Knowles laid the foundations of andragogy by making four assumptions about the attributes of adult learners (selfconcept, adult learner experience, readiness to learn, and orientation to learning), and he added a fifth component, motivation to learn, in 1984. Of the five concepts, selfconcept, adult learner experience, readiness to learn, and motivation to learn are similar to the components of Pink's (2009) theory.

Knowles' (1980) self-concept represents the result of a transition from being dependent to being self-directed in the 
life of a person as they mature. In Knowles' (1975b) description, self-directed learning is as follows:

"... in which individuals take the initiative, with or without the help of others, in diagnosing their learning needs, formulating learning goals, identifying human and material resources for learning, choosing and implementing appropriate learning strategies, and evaluating learning outcomes." (p. 88)

This definition encapsulates the same notion as Pink's (2009) interpretation of autonomy in the workplace.

Knowles' (1980) second and fifth concepts, adult learner experience and motivation to learn, refer a growing pool of experience that represents an ever-increasing resource for learning. These concepts are similar to Pink's (2009) mastery; however, Pink's (2009) conceptualization of mastery assumes a deliberate effort from the employee, whereas Knowles' (1980) model adult learner experience embodies the accumulation of more and more experience, merely as a consequence of spending more time in the job. In this respect, Knowles' concept is similar to Reischmann's (2017) lifewide learning. As for the other concept, motivation to learn, in Knowles, Holton, and Swanson's (2014) theory, it is a direct consequence of entering unfamiliar territory: "each transition to a new stage creates a motivation to learn" (p. 207).

The third similarity in the two theories can be observed between Pink's (2009) concept of purpose and Knowles' (1980) readiness to learn, as they both tap into comparable domains: stepping beyond the self and contributing to a greater cause. Although Knowles' fourth concept, orientation to learn, does not have a corresponding match in Pink's (2009) motivation model, it is likely to have a pivotal role in motivating learning adults, as this component addresses the immediacy of knowledge application and a shift from "subject-centeredness to life-, task- or problemcenteredness" (Knowles et al., 2014, p. 46).

This orientation is manifest in adult learners' language learning, as foreign-language competence is applied in the increasingly interwoven global network of corporate relations. On a European level, foreign-language competence is defined as a key competence by Key Competences for Lifelong learning (The European Parliament and the Council of the European Union, 2006). This is substantiated by the fact that communication in a foreign language is necessary for employees to adapt to the accelerating changes of the globalized world. Foreign-language competence was last surveyed in 2016 (Eurostat, 2016) and during the survey, evidence of foreign-language competence did not have to be provided; therefore, the data are based on self-evaluation. The 2016 sample shows that only $42.4 \%$ of the Hungarian adult population speak foreign language, out of whom depending on their age $-20 \%-30 \%$ consider themselves proficient in the spoken foreign language.

If we take the above trends and figures into account, it is not surprising that organizations active in the Hungarian labor market are laying emphasis on improving and maintaining the language skills of their workforce even today. According to the publication Adult education - training, 2018 (Central Statistical Office, 2018), 30.5\% of the
Hungarian workforce participated in non-institutionalized adult education in 2016, which is a 5\% increase on the year before. Corporate language education is the fifth most popular way of adult training in corporate contexts preceded only by professional training courses, conferences, team building, and professional presentations.

This tendency on the Hungarian labor market is in line with the broader European context (see, e.g., Billett, 2018; Reischmann, 2017), and the European Commission (2018) recognizing the importance of lifelong learning - has established the ET 2020 Working Group 2016-2018 on adult learning. The final report of the working group justifies the significance of adult learning in the workplace with six arguments, which include providing an accessible and attractive way for adults to maintain and update the knowledge and skills they need for life, at work, and at home. This is beneficial not only for them, but their employers and member states alike, as they raise the productivity and competitiveness of the countries that they work in. In addition, according to the report, adult learning "supports social and economic (re-)integration of vulnerable groups, inclusion, social cohesion and equality; and improves adults' lifelong employability" (p. 6).

\section{Current trends in L2 autonomy}

While several detailed definitions of autonomy exist in the literature, for the purpose of this paper, Benson's (2011) definition "autonomy is the capacity to take control of one's learning" (p. 58) will be used. The first decade of the new millennium witnessed an unprecedented, threefold surge in the number of studies on autonomy in language learning compared to the three decades of L2 autonomy research before 2000 (Benson, 2011). This increased interest called for an overview of the field produced by Benson (2007, 2011). While the field of L2 autonomy is still thriving (see, e.g., Csizér \& Kormos, 2012; Kormos \& Csizér, 2014), Chik et al. (2018) argued for new research agendas due to the changing perspectives on language learning and teaching.

The areas of research they proposed for investigation were the following: (a) the relevance of the concept of autonomy in developing countries and disadvantaged learning and teaching contexts; (b) the impact of the teacher and censorship on how autonomy is conceptualized; (c) how digital interaction and space change the dimension of autonomy in group dynamics; and (d) how new configurations of space will necessitate new ways of learning.

Even though Hungary in 2019 is generally not regarded as a developing country, it is neither a Western one, nor an East Asian one; nevertheless, it would be intriguing to position it culturally on an East-West axis. The reason why this point may be considered relevant here is that, traditionally, autonomy has been regarded as a Western concept (Chik et al., 2018), even if many scholars object to this "falsely constructed binary with regard to East Asian contexts" (p. 2) (e.g., Aoki, \& Smith, 1999; Littlewood, 1999). Smith et al. (2018) argue that autonomy is not limited culturally; instead, it is the lack of resources that constitutes a critical criterion for learners and teachers to engage in it. Gao (2018) - in his study that drew data from teachers' 
Internet discussion groups - contradicts their argument by finding that autonomy is hindered by cultural tradition "that imposes high expectations on teachers and subjects them to public scrutiny with reference to expectations" (p. 42).

Another aspect of the proposed lines of research that is relevant for this paper is the impact of the teacher on autonomy, as autonomy also involves interdependence between teachers and learners. As teachers are increasingly being regarded as significant players in promoting L2 autonomy (e.g., Deters, Gao, Miller, \& Villanova, 2014; Murray, Gao, \& Kamb, 2011), it is interesting to investigate how teachers enhance or hinder learner autonomy, how they cope with institutional constraints, such as corporate educational policies and language exam requirements, and how in their endeavors to promote autonomy they affect the L2 motivation of their learners.

\section{The teacher's role in $\mathrm{L} 2$ motivation}

In the field of L2 motivation research, the teacher's role in motivating learners has remained an underresearched niche to this day (Dewale, Gkonou, \& Mercer, 2018). If we narrow our focus on motivating adult learners of English in an English as a foreign language (EFL) context, there are very few empirical studies. These studies contain Shoaib and Dörnyei's (2005) interview study that examined the participants' motivational history; Szaszkó's (2007) study that explored the impact that intercultural contacts had on adult Hungarians' motivation; Ishtiaq, Zuraina, and Salem's (2015) study on how cooperative learning strategy affects the motivation of Saudi EFL adult learners; and Kálmán's (2018) study that addresses specifically the teacher's impact on motivating adult learners in corporate contexts.

Recent years of L2 motivation research have been characterized by a "surge in publications related to the pedagogical aspects of motivation" (Lamb, 2017, p. 304), and Lamb (2017) highlighted some novel phenomena in the field. For a start, he emphasized the changing nature of the teacher-learner relationship, in which language learners expect to be entertained as much as educated. This phenomenon is even more apparent in corporate contexts, where teachers are not considered authoritative figures, but are regarded as educational service providers on a level playing field with the learner (Kálmán, 2018). Apart from describing a change in learners' attitudes toward the teacher, Lamb (2017) also laid great emphasis on the outright description of the teacher as a motivator:

"any good teacher is, by definition, a motivator of learning ... teachers who actually target learner motivation could nurture and strengthen it so that it promotes greater learning effort during the course, produces even better results, and perhaps even carries forward to future periods of study." (p. 306)

The teacher's central role in motivating language learners has been further strengthened by the tendency that a growing number of studies have reached back to the cognitive situated period, and also revived and empirically validated Dörnyei and Csizér' (1998) and Dörnyei's (2001) motivational strategies (e.g., Guilloteaux, 2013; Ruesch, Bown, \&
Dewey, 2012; Sugita McEown \& Takeuchi, 2014; Wong, 2014). Simultaneously, qualitative studies have proved that "some individual teachers express more agency than others in developing their learners' motivation, despite working in similar contexts" (Lamb, 2017, p. 314), which he labeled responsiveness, and defined as "the personal quality of empathy [...] built up over years of practice, which defines the successful motivator" (p. 315).

\section{METHODS}

While the literature review attests to an elaborate conceptualization of the fields discussed, as stated in "Introduction" section, the cross section of these fields requires more detailed empirical support. Therefore, in order to fill this research niche, I set out to explore how adult L2 learners' motivation is affected by autonomy generated by corporate contexts and teachers working in these contexts. Therefore, the research questions I wanted to answer were:

$R Q 1$ : How does autonomy generated by the learning environment affect adult English learners' L2 motivation in Hungarian corporate contexts?

$R Q 2$ : How does autonomy generated by the language teacher affect adult English learners' L2 motivation in Hungarian corporate contexts?

As stated in "Introduction" section, this paper synthesizes the findings of previous studies (Kálmán, 2015a, 2015b, 2016b, 2018) conducted in corporate environments and focuses on the role of context- and teacher-generated autonomy on L2 motivation. The guiding principle of designing the research methodology of the studies was to address all stakeholders involved: adult learners of English in a corporate environment, teachers working in such contexts, as well as HR policy and decision-makers. By examining the focus of the enquiry from these three angles, data source triangulation was ensured.

In order to answer the first research question of this paper related to the effect of context-generated autonomy on the motivation of adult L2 learners, the results of two interview studies conducted with HR policy makers (Study 1) and adult L2 learners (Study 2) will be synthesized and presented. As regards, the second research question related to the effect of teacher-generated autonomy, the findings of two interview studies with L2 teachers (Study 3) and L2 learners (Study 4) will be discussed (see Table 1 for a detailed description of the research method of the individual studies; Kálmán, 2015a, 2015b, 2016b, 2018).

\section{The participants}

All the participants of the studies work in organizations employing more than 250 employees representing a wide range of industries including the automotive; baby, feminine, and family care; banking; construction; electricity; fast-moving consumer goods; gas; information technology; insurance; nuclear; pharmaceutical; telecommunications; tobacco; and trading industries; as well as public administration. Six of the organizations were Hungarian stateowned, 12 were public limited companies including 2 American, 2 German, and 1 Austrian multinationals. 
Table 1. Detailed description of the research method of individual studies and distribution of the participants

\begin{tabular}{llcc}
\hline & Focus of the study & Research method & Participants \\
\hline Study 1 & Context-generated autonomy & Interview & 18 HR policy makers \\
Study 2 & Context-generated autonomy & Interview & 16 learners + 1 HR manager \\
Study 3 & Teacher-generated autonomy & Interview & 18 teachers \\
Study 4 & Teacher-generated autonomy & Interview & 5 learners \\
\hline
\end{tabular}

Note. HR: human resource.

Fourteen of them are based in Budapest, four in the country (for a detailed distribution of the participants, see Table 1).

\section{Data collection and analysis}

The data collection took place between December 2014 and June 2016. In each stage of the research, I conducted interviews with the participants in their mother tongue (Hungarian and English, respectively). The interviews were audio-recorded with the consent of the participants and transcribed verbatim. The interview transcripts yielded about 200,000 words of data altogether (out of which 60,000 words came from the interviews with HR policy makers; 70,000 words with adult learners; and 70,000 with teachers). The data collected through the interview studies were analyzed using Crabtree and Miller's (1999) template organizing style. The data analysis started out with a template of codes, a code manual, which was based on background information on the topic. The transcribed texts were coded using this predetermined template, which was complemented and fine-tuned during the data analysis process. The data were analyzed for each of the original studies individually. For this paper, the results of the original studies were studied and synthesized, and only findings related to autonomy are presented.

\section{RESULTS}

This chapter presents the autonomy-related results of the four studies above. In the first section "Context-generated autonomy," the findings related to the autonomy-generating capacity of the context will be described by synthesizing the emerging themes of two interview studies conducted with 19 HR policy makers and 16 adult learners. The second section "Teachers' views on their capacity to generate autonomy" will summarize the results related to autonomy generated by teachers working in corporate environments based on the views of 18 teachers and 5 adult learners.

\section{Context-generated autonomy}

Based on the results of the two interview studies that investigated HR policy makers' and adult learners' views on the autonomy-generating capacity of corporate contexts, it can be ascertained that the above capacity of these contexts that fosters L2 autonomy arises from two sources. First, it is an indirect repercussion of the organic evolution of corporate language education systems in Hungary.
Second, it is the consequence of current corporate languagetraining practices.

\section{Organic evolution of corporate language education schemes}

The geopolitical and economic changes that took place at the beginning of the $1990 \mathrm{~s}$, and the appearance of multinational companies in Hungary, made it necessary for organizations to launch on-site language courses to accommodate their workforce to the new environment. The language education systems of the investigated organizations have been evolving organically since the political system change in Hungary in 1989 up to this day. They have gone through several stages of development, and we can observe various circumstances that have promoted autonomous learning in each of these stages. In the 1990s, corporate language education was a newly emerging phenomenon and need, and the absence of existing guidelines and best practices meant that it was able to evolve organically from within, without external intervention, through the constant and dynamic interaction of all stakeholders involved: learners, teachers, language schools, HR policy makers, business partners, and the management alike. Peter, a HR manager, expressed this in the following way:

"As we have never had anything to rely on, and we still don't get any guidance or instruction from our regulator as to how we should organise the courses, what we should teach to our employees, what we've been doing over the years is basically trial and error. We are still experimenting with many novel approaches and methods, we keep the good ones, and we throw out the ones that don't work."

Lily, an HR associate, described this in different words:

"This air of experimentation lends a sense of freedom to the whole process. Everybody's opinion is welcome, moreover, we have always encouraged our employees to come up with their own initiatives that they feel could improve our language courses, and they have always been happy to contribute new ideas."

The need for corporate language learning was further strengthened when organizations joined European or global networks of similar organizations after Hungary joined the European Union in 2004. By the 2000s, employees had familiarized themselves with the English jargon of different industries; however, Oliver, a learner, added that, "It's the easiest part because you meet it on a daily basis" (p. 3), and 
he found it important to highlight that the language related to a particular industry could only be learnt if one worked in the profession:

"... this was the time when I started to realise that it was impossible to find the expressions we used in dictionaries. I had realised by this time that it was very rare that an outsider knew the specific vocabulary to such an extent that it would be $100 \%$ acceptable. We had to make efforts on our own to pick up the necessary vocabulary, but we received a lot of support from our employer, as well as our language teachers." (p. 3)

Josh, another learner, underlined that in the 2000s, they were given a free hand to bring English teachers on board of the organizations, instead of the company announcing a tender for language schools:

"Later, as my English was more advanced, I realised that the person of the teacher was getting increasingly important. On the one hand, I wanted to spend the time I devoted to learning English in the company of a person I liked, on the other hand, in the 2000s you were already able to find very good teachers, which was obviously not the case in the 1990s when sorry to say, but many of the English teachers were retrained Russian teachers, a few lessons ahead of you in their studies." (p. 2)

With the organic development of corporate language education systems, in the past decade, the importance of tailormade services has emerged, which has made it possible for learners to make a choice in various aspects of their language training.

\section{Current corporate language-training practices}

A corporate environment facilitates and simultaneously requires tailor-made teaching. It enables the teacher to personalize teaching, as an overwhelming majority of language courses are one-to-one, or are organized in small groups of maximum four learners in this context. On one hand, it is a requirement from the commissioners, the organizations who expect language educators to provide services that are tailored to the companies' specific needs. All of the participants confirmed that personalizing the lessons had a strong motivating influence on the learners, as they felt they had a choice, their needs were attended to, they could focus on what they really needed, and in this way, they could develop faster, which in turn enhanced their motivation. It emerged during the interviews that corporate contexts are not as highconstraint as schools. Fiona said the following on this, "I' $m$ lucky, because it's not like in a school when you have a book. I have what we together choose to have, the main thing is to achieve the set goal by the end of the course" (p. 6). Albert expressed a similar notion, "I have the freedom, the only thing I pay attention to is to stay within the frames of the particular corporate culture" (p. 7).

Current corporate language-training practices promote learner autonomy in several ways, as based on the interviews with the HR policy makers, it turned out that language learning is optional in all the organizations investigated, and is available for both managers and employees. The lessons are generally held in the morning hours or late afternoon and evening hours, typically before or after core time for employees, whereas managers tend to choose the time of their lessons whenever it is most convenient for them. Practically, this can be any time on a weekday between 6 a.m. and 9 p.m. With the exception of one multinational, all of the participants unanimously stated that their employees were required to take some kind of language exams at the end of their courses or at the end of the term specified in their educational contract. However, it is up to them what kind of exam they take. Six of the employers prefer bilingual exams on the grounds that employees should be able to translate as well, but they do not mind what kind of exam the employees pass as long as it is accredited. Two of the organizations have devised their own in-house exams in cooperation with their employees and partner language schools, and test their learners with real-life tasks, for example, giving a presentation or writing a prompt e-mail, which they claim provides a more credible assessment on the skills the learners are expected to master.

The expectations that the majority of HR policy makers formulated during the interviews toward language teachers and language schools were flexibility, tailor-made teaching, and the ability to teach English for specific purposes (ESP) as well, all of which foster choice. James, an HR manager, elaborated on flexibility in this way:

"By flexibility I also mean that if the employees come up with emerging needs during the course or on behalf of the employer and I change the goal, the focus, or the content of the course, the teacher should be flexible in adjusting to the new situation." (pp. 1-2)

Under the term of flexibility, other respondents cited flexibility in time, place, syllabus, course book, pace, learning style, and availability. There was an equally outstandingly high number of references to the need for tailor-made teaching, which very often took shape in teaching ESP for the learners. Julia expressed this in these words:

"It is absolutely important that the teachers should be very pragmatic. We don't expect our managers to have a very thorough knowledge of the English grammar or to be able to read Shakespeare in original. The teachers have to prepare our managers to communicate in ANY situation. Our managers have to conduct very tough negotiations. They are very efficient in this in Hungarian, and they should be just as efficient in English, too." (p. 2)

Peter, another HR manager, was of a similar opinion, "in the limited time they can devote to learning, I'd really like them to practice only those particular situations that they encounter day by day" (p. 3). On the same topic, George said the following, "the quality of the education is defined by how flexibly the teacher can accommodate to the specific needs" (p. 3), whereas Kate emphasized the following, "if anybody needs technical English, I think it would be great if the teacher had that kind of knowledge so that they could discuss such issues" (p. 1). John described a very successful cooperation with a language school as follows: 
"Their greatest competitive edge is that they have been here for 20 years, and by now, they have fully developed their tailor-made courses specially designed for us. They have developed how to teach the technical language, web-based solutions, which focus on what you have to say in a meeting, how you have to say it, and how you can solve problems in English, etc." (p. 3)

The findings above demonstrated how corporate contexts have fostered autonomous language learning through their organic development, and their current language training practices by offering adult language learners choices in learning a foreign language, and by requiring language educators to be flexible and tailoring their services to the needs of employees. The next chapter presents how L2 autonomy is promoted by teachers in this context.

\section{Teacher-generated autonomy}

On the basis of the two interview studies that investigated teachers' and adult learners' views on the autonomygenerating capacity of teachers working in corporate contexts, it can be stated teachers can promote adult learners' autonomy by tailoring their teaching in response to their learners' needs in multiple ways. Besides, they also encourage learners to deal with English when they are not in class, and share a variety of ways with them how to do it. Apparently, as it turned out, learners in this context cannot always handle the amount of autonomy they are given, and the effect might be counterproductive. First, findings arising from the teachers' views will be presented followed by those of the learners.

\section{Teachers' views on their capacity to generate autonomy}

As was described in the previous section, a corporate environment in itself generates autonomy, due to its peculiar features, as well as the expectations of organizations and HR policy makers that require language educators to listen to the needs of the commissioner and learners alike. Teachers working in this environment strengthen this inherent characteristic of the context and contribute to creating an atmosphere that fosters learner autonomy. It comes to them naturally, and they do it rather out of their own conviction than the pressure to meet corporate expectations. Jackie expressed this in the following way, "personal needs are very important, because adults know what they want, what they need, so tailor-making the lessons accordingly is very important" (p. 4). Tailor-made teaching for Anna means that she tries out various teaching methods to find the one that best meets the learning style of the participants:

I keep asking for personal feedback, on the basis of which I can make tailor-made exercises for the learners. I draw up the tailor-made syllabi on the basis of their individual needs, as well. I'm very flexible with homework. I don't care when they do it as long as they do it. They can hand it in any time and they appreciate it and they do hand it in. Another thing that I always ask them is to bring in the materials they work with. That's the best source of ESP and I can make exercises based on that. (p. 9).
It is interesting to note that while having a choice is generally liberating and welcome, offering too many alternatives and freedom might be counterproductive, especially with learners over the age of 45-50 years. Several of the participants highlighted the fact that adult learners over the age of 45-50 years shy away when they perceive how many choices they are given and how much attention they are paid to. Ian expressed this as follows:

"My older learners cannot handle freedom as well as the younger ones. For them, the teacher is still the authoritative figure it once used to be. Furthermore, they can feel inconvenient by the amount of attention they are given. Many of them prefer to be told what to do and how to do it."

According to the teachers, another tool that promotes learner autonomy is a free choice of conversation topics in the classes. In Peggy's view, a teacher-adult learner relationship might be much more complex than a simple work relationship when one party gives over their cognitive information on a given subject (in this case, the English language) to the other party. This is due to the fact that the subject of this transaction is a language, which makes it possible for the students to express themselves, share their opinions on a myriad of issues, and speak about themselves. If these opinions and feelings are met with the responsive ears of a teacher, a multilevel cooperation evolves between the teacher and the student, which in turn creates a nurturing and motivating environment where language acquisition takes place more effectively.

Anna expressed her opinion on why she considers it important to let learners express what they feel like talking about:

\begin{abstract}
"Free conversation is very important. This is how you can get to know your students. It's a more personal relationship. I often teach guys, so we always discuss what they do in their free time: electronics, sport, whatever we have in common. I can find out what is important for whom, and later we can talk about topics that are important for them." (p. 6)
\end{abstract}

Adam emphasized that free conversation has the added benefit that the teacher and the students usually end up discussing work-related issues: "We generally start talking about what they are doing in the workplace, what their current tasks are, what kind of projects they have related to English and naturally they get engaged in this" (p. 6). Bill also confirmed the above and emphasized the importance of asking good questions, which he learnt in a coaching course:

"I start every lesson by asking how they are. They speak
about themselves, and they can talk about any kind of
problems. I don't mind listening to work-related pro-
blems, either. Obviously, I cannot help them solve these
problems, but I can ask them questions that might help
them. I used to do this before, but since I completed my
coach training, I've been using these questions more
consciously. The technique of asking good questions is
very important. You don't have to know what kind of 
problems they have at the company, the less I know, the better, still, I can ask questions that help them a lot." (p. 6)

Many of the teachers emphasized that apart from offering their learners' choices in the lesson, they also consciously call for learners' attention to what they can do out of the classroom to use and learn English. Helen expressed this in the following way:

"I always tell them that the time we spend together in the lessons is very limited, so they have to make conscious efforts to learn and practise English in their workplace and in their private lives as well. I show them how I use English in my private life, I recommend applications and websites where they can practice the language independently." (p. 3)

Craig and Dawn mentioned another way of raising their learners' awareness of independent language use out of the classroom. In Craig's words:

"I think it is important to let them know that their proficiency will depend on the amount of time they use the language, not the amount of time they learn it. As a result, I always encourage them to participate in international conferences, presentations to foreign professionals, international meeting, wherever they can practise their English." (p. 2)

After the teachers' views, in the next section, the findings related to the learners' views on teacher-induced autonomy are presented.

\section{Learners ' views on teachers' capacity to generate autonomy}

While the teachers interviewed underlined the significance of providing learners with a choice in and out of the classroom in order to foster autonomous language learning, the learners participating in the interviews confirmed the beneficial impact of these practices. There was one theme however that did not emerge in the interviews with the learners, the importance of a free choice of conversation topic. In connection with tailoring language teaching in response to the individual preferences and needs of the learner, John elaborated on how the freedom he is given motivates him:

"My teacher personalises everything: the length and the time of the lessons, the frequency of the lessons, the course books we use, the handouts she makes. It's very important for me to feel that I am given special attention, special care: I can sense that everything has specially been made for me." (p. 6)

Peter expressed that the attention he is given can be further divided into a triad: communicational, personal, and pedagogical attention:

"There is communicational attention when I get immediate feedback on what I say, there is also personal attention, which is again important, when you feel that habits are being formed, like we drink coffee or something in the lesson, or when a special atmosphere is created, and there is pedagogical attention that manifests itself in giving me personalised homework." (p. 7)

John added that being given a choice also enhances his efficiency, "if I don't get personalised assignments, maybe I have to work on something that I'm already good at. It's a waste of time. It only makes sense if I can practise something I still don't know." (p. 5), while Kate emphasized the importance of autonomy in goal-setting:

"I think very personal goals have to be set right at the beginning and my teacher helps me a lot with this. She tells me what's realistic, and she always tells me to be patient with myself. We discuss what and by what deadline I should achieve, but in the end, I always feel that it's my decisions. I think she's very clever at that." (p. 5)

Kate, John, and Peter revealed that it was their teacher who opened up their eyes about the importance of language use out of the classroom. Kate expressed her opinion on this as follows:

"I know it's trivial, and I should have known myself, but somehow, I always thought that what mattered in language learning was what happened in the classroom. My teacher changed my perspective completely when she told me that what really mattered was using the language out of the classroom. Not that I want to understate the importance of her work of course, but I think she is right." (p. 4)

Interestingly, two of the participants explained that even though they found tailor-made teaching very motivating, they admitted that receiving personalized attention was sometimes perceived by them as emphasizing their own importance, which - as they claimed - was not proper in Hungarian culture. Another inconsistency that emerged from the data was the discrepancy between the teachers' and the learners' opinion about the importance of a free choice of conversation topic. As was confirmed by several of the teacher participants, providing learners with the opportunity to speak about practically anything was perceived as one of the most liberating and thus motivating practices by the teachers. It would require another selfcontained study to explore why this theme did not emerge during the learner interviews.

\section{DISCUSSION}

The findings related to the autonomy-generating capacity of the context confirm several statements introduced in the literature review concerning the spread of English in the Hungarian labor market (Földi et al., 2013), the role it plays in acquiring knowledge capital (Sturcz, 2010), as well as knowledge management (Hishop, Boshua, \& Helms, 2018). Initially, the circumstances that necessitated the introduction of corporate language training came from outside the organizations. As they did not happen overnight, and were not 
superimposed on companies by the controlling institution or regulators, the development has been smooth and organically driven by the actual needs of the stakeholders. The empowerment it brought about has created a highly motivating learning environment for adult language learners.

It does not mean that there is no room for improvement, as the development of corporate organic systems cannot spare lifelong learning either, in response to constantly emerging new needs. Nevertheless, current languagetraining practices of the investigated organizations meet all the criteria of the European Commission's (2018) ET 2020 Working Group 2016-2018 initiative, as well as the components of Pink's (2009) motivation theory in the workplace, and Knowles' $(1980,1984)$ assumptions about andragogy. Through language learning, employees have the opportunity to grow (mastery), can do it in autonomous ways (autonomy), and can do it with a goal in mind (purpose) that benefits not only their professional development, but also their employers, and in a broader sense, their private lives and communities likewise.

Apart from the motivating environment, teachers working in this environment can also contribute to learners' motivation in several ways that include fostering adult learners' autonomous learning. Based on the findings in "Teacher-generated autonomy," the most effective tool teachers possess to promote autonomous learning is providing learners with choices and tailor-making their teaching in response to learners' choices. These choices refer to the autonomous use of traditional sources of knowledge, online sources of knowledge, learning strategies and meta-strategies, as well as classroom processes, that is, they cover four areas of L2 autonomy defined by Benson (2011).

There appear to be three underlying reasons why tailormade teaching is so important in this context. First, for an organization, language teaching is similar to a whole array of services the organization purchases. Similarly to any other service in the market, being tailored to the specific needs of a client means a competitive advantage over the services of other suppliers who do not personalize their services to the same extent. Second, teaching in corporate courses can be far more easily personalized than in institutional school settings, as the majority of these courses are one-to-one, while learning in groups usually entails a maximum of five members. While the first two reasons are in fact external to and independent of the learner, the third one explains how tailor-made teaching can contribute to motivation in the learner. By tailoring the course in response to the needs and requests expressed by the learner, learner autonomy is enhanced. If the teacher provides a choice, learning becomes more relevant to the learner's needs and preferences. This autonomy-supportive behavior has been associated with learners' self-determined motivation and positive feelings about learning (see, e.g., Assor, Kaplan, \& Roth, 2002; Benson, 2007, 2011; Black \& Deci, 2000; Little, 1991). The importance of being responsive to learners' needs was articulated by a both large number of teachers and learners. This lends further empirical evidence to the notion of responsiveness, which, according to Lamb (2017), is the key characteristic of a successful motivator.
The most controversial theme in the survey is the free choice of conversation topics, which did not emerge in the interviews with the learners; however, both HR policy makers and teachers highlighted its importance in increasing autonomy and thus motivation. It is possible that learners do not notice or are unaware of the underlying motivational influence that talking about anything in the lessons brings about. Another possibility is that learners might find it embarrassing to admit that sometimes they come to the lessons specifically to vent their problems, as has been expressed by teachers and HR managers. The underlying cause of this phenomenon might also be culturally determined, similarly to the finding that some learners found it hard to come to terms with the choices and attention they were given, as they felt these intentions of the teacher emphasized the importance of the learners which, according to some learners, was not proper in Hungarian culture. This result contradicts Smith et al.'s (2018) argument that autonomy is not limited culturally; instead, it is a lack of resources that constitutes a critical criterion for learners and teachers to engage in it.

\section{CONCLUSIONS}

This paper investigated the role of context- and teachergenerated autonomy on the L2 motivation of adult learners in corporate contexts in Hungary. By synthesizing the results of four previous interview studies conducted with 19 HR policy makers, 18 L2 teachers, and 21 adult learners, it sought to answer two research questions on: (a) how autonomy generated by the learning environment affected adult English learners' L2 motivation in Hungarian corporate contexts; (b) how autonomy generated by the language teacher affected adult English learners' L2 motivation in the same contexts. The findings have revealed that corporate contexts in Hungary promote adult learners' motivation by fostering their autonomous learning. This positive effect is achieved by the ongoing organic development of corporate language education systems, as well as the current language-training practices that meet the requirements of andragogy and modern motivation models independent of L2 motivation theories. The results have also evidenced that teachers working in these contexts exhibit a strong motivating capacity through enhancing autonomous language learning primarily by being responsive to their learners and offering them choices related to different aspects of language learning.

While all HR policy makers, teachers, and learners participating in the studies agreed on the above, there was one area where a discrepancy emerged between the opinions: the motivating impact of a free choice of conversation topics. This disagreement calls for further investigation to explore whether it is the teachers who tend to overestimate its motivating capacity or the learners who tend to underestimate it. Another interesting line of research might be the cultural variation of the embeddedness of autonomy or corporate language teaching contexts in other countries in the world. 
Funding sources: None.

Author's contribution: The author has full access to the references included in this analysis and takes responsibility for the integrity and accuracy of the study.

Conflict of interest: The author declares no conflict of interest.

\section{REFERENCES}

Aoki, N., \& Smith, R. (1999). Autonomy in cultural context: The case of Japan. In S. Cotterall \& D. Crabbe (Eds.), Learner autonomy in language learning: Defining the field and effecting change, Bayreuth contributions to glottodidactics (pp. 19-28). Frankfurt am Main, Germany: Peter Lang.

Assor, A., Kaplan, H., \& Roth, G. (2002). Choice is good, but relevance is excellent: Autonomy-enhancing and suppressing teacher behaviours predicting students' engagement in schoolwork. British Journal of Educational Psychology, 72(2), 261-278. doi:10.1348/000709902158883

Benson, P. (2007). Autonomy in language teaching and learning. Language Teaching, 40(1), 21-40. doi:10.1017/S0261444 806003958

Benson, P. (2011). Teaching and researching autonomy (2nd ed.). London, UK: Pearson Longman.

Billett, S. (2018). Distinguishing lifelong learning from lifelong education. Journal of Adult Learning, Knowledge and Innovation, 2(1), 1-7. doi:10.1556/2059.01.2017.3

Black, A. E., \& Deci, E. L. (2000). The effects of instructors' autonomy support and students' autonomous motivation on learning organic chemistry: A self-determination theory perspective. Science Education, 84(6), 740-756. doi:10.1002/ 1098-237X(200011)84:6<740::AID-SCE4>3.0.CO;2-3

Chik, A., Aoki, N., \& Smith, R. (2018). Introduction. In A. Chik, N. Aoki, \& R. Smith (Eds.), Autonomy in language learning and teaching: New research agendas. London, UK: Palgrave Macmillan.

Crabtree, B. F., \& Miller, W. L. (1999). Using codes and code manuals. In B. F. Crabtree \& W. L. Miller (Eds.), Doing qualitative research (pp. 163-177). London, UK: Sage.

Csikszentmihalyi, M. (1988). The flow experience and its significance for human psychology. In M. Csikszentmihalyi \& I. S. Csikszentmihalyi (Eds.), Optimal experience: Psychological studies of flow in consciousness (pp. 15-35). Cambridge, UK: Cambridge University Press.

Csizér, K. (2018). Some components of language learning experiences: An interview study with English teachers in Hungary. In M. Lehmann, R. Lugossy, M. Nikolov, \& G. Szabó (Eds.), UPRT2017: Empirical studies in applied linguistics (pp. 1-14). Pécs, Hungary: University of Pécs.

Csizér, K. (2019). The language learning experiences and their perceived impact on teaching: An interview study with English teachers in Hungary. In M. Sato \& S. Loewen (Eds.), Evidence based second language pedagogy: A collection of instructed second language acquisition studies. New York, NY: Routledge.
Csizér, K., \& Kormos, J. (2012). A nyelvtanulási autonómia, az önszabályozó stratégiák és a motiváció kapcsolatának vizsgálata [Investigating the interaction of motivation, self-regulatory strategies, and autonomous learning behaviour]. Magyar Pedagógia, 112(1), 3-17.

Deci, E. L., \& Ryan, R. M. (1985). Intrinsic motivation and self-determination in human behavior. New York, NY: Plenum.

Deters, P., Gao, X., Miller, E. R., \& VItanova, G. (2014). Theorizing and analyzing agency in second language learning: Interdisciplinary approaches. Bristol, UK: Multilingual Matters.

Dewaele, J.-M., Gnokou, C., \& Mercer, S. (2018). Do ESL/EFL teachers' emotional intelligence, teaching experience, proficiency and gender affect their classroom practice? In A. J. Martínez (Ed.), Emotions in second language teaching. Cham, Switzerland: Springer.

Dörnyei, Z. (2001). Motivational strategies in the language classroom. Cambridge, UK: Cambridge University Press.

Dörnyei, Z., \& Csizér, K. (1998). Ten commandments for motivating language learners: Results of an empirical study. Language Teaching Research, 2(3), 203-229. doi:10.1177/ 136216889800200303

Dutton, J. E., \& Wrezniewsky, A. (2001). Crafting a job: Revisioning employees as active crafters of their work. Academy of Management Review, 26(2), 179-201. doi:10.5465/amr.2001. 4378011

Eurostat. (2016). Foreign language skills statistics. Retrieved 22 February, 2019, from https://ec.europa.eu/eurostat/ statistics-explained/index.php/Foreign_language_skills_statistics \#Analysis_of_those_who_consider_themselves_proficient_in_ their_best_known_foreign_language

Fejes, A., Olson, M., Rahm, L., Dahlstedt, M., \& Sandberg, F. (2018). Individualisation in Swedish adult education and the shaping of neo-liberal subjectivities. Scandinavian Journal of Educational Research, 62(3), 461-473. doi:10.1080/0031 3831.2016.1258666

Földi, K., László, É., Szűcs, R. S., \& Máté, Z. (2013). A munkaerőpiacon szükséges nyelvi kompetenciák feltérképezése kvalitatív eszközökkel [Mapping language competencies necessary in the labour market]. Szolnoki Tudományos Közlemények, 17, 140-151.

Gao, X. (2018). Language teacher autonomy and social censure. In A. Chik, N. Aoki, \& R. Smith (Eds.), Autonomy in language learning and teaching: New research agendas. London, UK: Palgrave Macmillan.

Graddol, D. (2006). English next: Why global English may mean the end of 'English as a foreign language'. London, UK: The British Council.

Guilloteaux, M.-J. (2013). Motivational strategies for the language classroom: Perceptions of Korean secondary school English teachers. System, 41(1), 3-14. doi:10.1016/j.system.2012. 12.002

Hislop, D., Boshua, R., \& Helms, R. (2018). Knowledge management in organisations: A critical introduction. Oxford, UK: Oxford University Press.

Ishtiaq, M., Zuraina, A., \& Salem, M. (2015). The effects of Student Teams Achievement Division (STAD) on motivation of Saudi EFL adult learners. International Journal of Language Education and Applied Linguistics, 3, 11-24. Retrieved from http://journal.ump.edu.my/ijleal/article/view/471/87 
Kálmán, Cs. (2015a). Magyarországi nagyvállalatok nyelvoktatási gyakorlata, és nyelviskolákkal, nyelvtanárokkal szemben támasztott elvárásaik 2015-ben [Corporate language education, and corporations' expectations of language schools and language teachers in Hungary in 2015]. Modern Nyelvoktatás, 21(4), 3-23.

Kálmán, Cs. (2015b). The teacher's role in generating and maintaining the motivation of adult learners of English in a corporate setting. Working Papers in Language Pedagogy, 9, 1-21.

Kálmán, Cs. (2016a). Corporate language education in Hungary: The teacher's role in generating and maintaining the motivation of learners of English (Unpublished $\mathrm{PhD}$ dissertation). Eötvös University, Budapest, Hungary.

Kálmán, Cs. (2016b). A nyelvtanár szerepe vállalati környezetben angol nyelvet tanuló felnőtek motivációjában, három kutatás tükrében [The language teacher's role in motivating adult learners of English in a corporate context, in light of three studies]. Neveléstudomány, 4, 46-63. doi:10.21549/ NTNY.16.2016.4.4

Kálmán, Cs. (2018). EFL teachers' motivation and motivational impact in corporate contexts. Journal of Adult Knowledge and Innovation, 2(1), 33-47. doi:10.1556/2059.02.2018.03

Knowles, M. (1975a). Self-directed learning: A guide for learners and teachers. New York, NY: Association Press.

Knowles, M. (1975b). Adult education: New dimensions. Educational Leadership, 33(2), 85-88.

Knowles, M. S. (1980). The modern practice of adult education: From pedagogy to andragogy. Englewood Cliffs, NJ: Prentice Hall/Cambridge.

Knowles, M. S., \& Associates. (1984). Andragogy in action: Applying modern principles of adult education. San Francisco, CA: Jossey-Bass.

Knowles, M. S., Holton, E. F., \& Swanson, R. A. (2014). The adult learner: The definitive classic in adult education and human resource development (6th ed.). London, UK: Routledge.

Kontráné, H. E., \& Csizér, K (2011). Az angol, mint lingua franca a szaknyelvet tanuló egyetemisták gondolkodásában [English as a lingua franca: The language learning dispositions of university students of ESP]. Modern Nyelvoktatás, 17(2-3), 9-25.

Kormos, J., \& Csizér, K. (2014). The interaction of motivation, self-regulatory strategies, and autonomous learning behaviour in different learner groups. TESOL Quarterly, 48(2), 275-299. doi:10.1002/tesq. 129

Központi Statisztikai Hivatal [Central Statistical Office]. (2016). Munkahelyi képzések, 2015 (elözetes adatok) [Corporate training programmes, 2015 (preliminary data)]. Statisztikai Tükör. Retrieved January 10, 2019, from http://www.ksh.hu/docs/ hun/xftp/stattukor/mhelykepzesek15.pdf

Központi Statisztikai Hivatal [Central Statistical Office]. (2018). Felnöttoktatás,- képzés (elözetes adatok) [Adult educationtraining (preliminary data]. Statisztikai Tükör. Retrieved January 10, 2019, from http://www.ksh.hu/docs/hun/xftp/ stattukor/felnottoktatas16.pdf

Lakner, Sz. (2016). A felnőttképzési módszerek jelentősége és kihivásai az emberi eröforrás fejlesztési gyakorlatban [The significance and challenges of adult training methods in the practice of developing human resources]. Pécs, Hungary: Lartco Consulting Kft.

Lamb, M. (2017). The motivational dimension of language teaching. Language Teaching, 50(3), 301-346. doi:10.1017/ S0261444817000088
Little, D. (1991). Learner autonomy 1: Definitions, issues and problems. Dublin: Authentik.

Littlewood, W. (1999). Teaching and researching autonomy (2nd ed.). London, UK: Pearson Longman.

Mercer, S., Glatz, M., Glettler, Ch., Lämmerer, A., Mairitsch, A., Puntschuh, S., Seidl, E., Težak, K., \& Turker, S. (2017). Moving between worlds: Teaching-based $\mathrm{PhD}$ identities from an ecological perspective. Journal of Adult Knowledge and Innovation, 1(1), 15-26. doi:10.1556/2059.01.2016.002

Murray, G., Gao, X., \& Lamb, T. (Eds.). (2011). Identity, motivation and autonomy in language learning. Bristol, UK: Multilingual Matters.

Pink, D. (2009). Drive: The surprising truth about what motivates us. New York, NY: Penguin.

Reischmann, J. (2017). Lifewide learning - Challenges for andragogy. Journal of Adult Learning, Innovation and Knowledge, 1(1), 43-50. doi:10.1556/2059.01.2017.2

Riley, P. (Ed.). (1985). Discourse and learning. London, UK: Longman.

Rogers, W. A., \& Mitzner, T. L. (2017). Envisioning the future for older adults: Autonomy, health, well-being, and social connectedness with technology support. Futures, 87, 133-139. doi:10.1016/j.futures.2016.07.002

Ruesch, A., Bown, J., \& Dewey, D. P. (2012). Student and teacher perceptions of motivational strategies in the foreign language classroom. Innovation in Language Learning and Teaching, 6(1), 15-27. doi:10.1080/17501229.2011.562510

Shanafelt, T. D., Balch, C. M., \& Bechamps, G. J. (2009). Burnout and career satisfaction among American surgeons. Annals of Surgery, 250(3), 463-471.

Shoaib, A., \& Dörnyei, Z. (2005). Affect in lifelong learning: Exploring L2 motivation as a dynamic process. In D. Nunan (Ed.), Learners' stories: Difference and diversity in language learning (pp. 22-41). Cambridge, UK: Cambridge University Press.

Smid, D. (2018). Hungarian pre-service teachers' motivation to become English teachers: Validating a questionnaire. Journal of Adult Knowledge and Innovation, 2(1), 19-32. doi:10.1556/ 2059.02.2018.02

Smith, R., Kuchah, K., \& Lamb, M. (2018). Learner autonomy in developing countries. In A. Chik, N. Aoki, \& R. Smith (Eds.), Autonomy in language learning and teaching: New research agendas. London, UK: Palgrave Macmillan.

Sturcz, Z. (2010). A munkaadók nyelvi elvárásai a szakértelmiséggel szemben: 2010 [Employers' language requirements towards professionals: 2010]. Modern Nyelvoktatás, 16(4), 7-18.

Sugita McEown, M., \& Takeuchi, O. (2014). Motivational strategies in EFL classrooms: How do teachers impact students' motivation? Innovation in Language Learning and Teaching, 8(1), 20-38. doi:10.1080/17501229.2012.741133

Szaszkó, R. (2007). Felnőtt nyelvtanulók motivációja és interkulturális találkozásai [The L2 motivation and intercultural encounters of adult language learners]. Iskolakultúra, 4, $138-144$.

The Council of Europe. (1997). Modern languages in the Council of Europe 1954-1997. Retrieved on 10 January, 2018, from https://rm.coe.int/modern-languages-in-the-council-of-europe1954-1997-international-co-o/1680886eae

The European Commission. (2018). Promoting adult learning in the workplace - Final report of the ET 2020 Working Group 2016-2018 on adult learning. Retrieved 10 February, 2019, 
from https://ec.europa.eu/social/main.jsp?catId=738\&langId= en\&pubId $=8112 \&$ furtherPubs $=$ yes

The European Parliament and the Council of the European Union. (2006). Recommendation of the European Parliament and of the Council of 18 December 2006 on key competences for lifelong learning (2006/962/EC). Retrieved 10 February, 2019, from http://eur-lex.europa.eu/legalcontent/HU/TXT/?uri= celex:32006H0962

Wong, R. M. H. (2014). An investigation of strategies for student motivation in the Chinese EFL context. Innovation in Language Learning and Teaching, 8(2), 132-154. doi:10.1080/ 17501229.2013.777449 